\title{
Antibacterial efficacy of several intracanal medicaments for endodontic therapy
}

\author{
Marta E. VALVERDE 1 , Pilar BACA ${ }^{2}$, Laura CEBALLOS ${ }^{1}$, M. Victoria FUENTES ${ }^{1}$, Matilde RUIZ-LINARES ${ }^{2}$ \\ and Carmen María FERRER-LUQUE² \\ ${ }^{1}$ Stomatology Area, Health Sciences Faculty, Rey Juan Carlos University, 28922 Alcorcón, Madrid, Spain \\ ${ }^{2}$ Department of Stomatology, School of Dentistry, University of Granada, Campus de Cartuja, Colegio Máximo s/n, 18071 Granada, Spain \\ Corresponding author, Laura CEBALLOS; E-mail: laura.ceballos@urjc.es
}

\begin{abstract}
The antibacterial efficacy of intracanal medicaments for 2 and 7 days, in open apex root canals contaminated with Enterococcus faecalis biofilms was compared. One hundred and thirty-eight standardized uniradicular human roots were inoculated with $E$. faecalis. Colony forming units (CFU) were recorded before and after medication. Samples were divided in two (2/7 days), and subdivided ( $n=8$ /group): triple antibiotic paste (TAP); double antibiotic paste (DAP); dental base paste (DBP), consisting of calcium hydroxide, propylene glycol and calcium carbonate; $\mathrm{DBP}+0.2 \%$ chlorhexidine $(\mathrm{CHX}) ; \mathrm{DBP}+0.2 \%$ cetrimide $(\mathrm{CTR}) ; \mathrm{DBP}+0.2 \% \mathrm{CHX}+0.2 \% \mathrm{CTR}$; $2.5 \%$ sodium hypochlorite $(\mathrm{NaOCl})$; and distilled water. At both periods TAP, DAP, DBP $+0.2 \% \mathrm{CHX}, \mathrm{DBP}+0.2 \% \mathrm{CTR}$ and $\mathrm{DBP}+0.2 \%$ $\mathrm{CHX}+0.2 \%$ CTR exhibited no growth (NG) of E. faecalis. Distilled water and $2.5 \% \mathrm{NaOCl}$ obtained the lowest CFU reduction. No growth with DBP was reached only at 7 days. CHX and/or CTR pastes were as effective as DAP and TAP. A 2-day period provided an effective disinfection.
\end{abstract}

Keywords: Regenerative endodontic therapy, Double antibiotic paste, Chlorhexidine, Cetrimide, Propylene glycol

\section{INTRODUCTION}

Endodontic infection or trauma of a permanent tooth can lead to pulp necrosis and, in the case of an immature tooth, to the interruption of tooth development, resulting in incompletely formed roots with wide open apices, reduced root length, and thin, fragile dentinal walls ${ }^{1)}$. Regenerative endodontic therapy (RET) has become a viable alternative in the treatment of immature teeth with pulpal necrosis as long as an adequate disinfection of the root canal system is guaranteed ${ }^{2}$. Most of RET clinical reports have used either triple antibiotic paste $(\mathrm{TAP})^{3-7)}$ or pure calcium hydroxide $\left(\mathrm{Ca}(\mathrm{OH})_{2}\right)$ paste $^{8-11)}$, as intracanal medicaments for this purpose.

$\mathrm{Ca}(\mathrm{OH})_{2}$ as unique intracanal medicament has been used in RET with satisfactory results ${ }^{8-11)}$. However, several authors claim that it can destroy cells with potential to differentiate into new pulp due to its high $\mathrm{pH}^{3)}$. Moreover, it may induce an uncontrolled calcification of the canal space that would prevent the ingrowth of soft tissue with an odontogenic potential ${ }^{9)}$.

TAP consisting of metronidazole, ciprofloxacin and minocycline, has been successfully used to disinfect the canals in RET, achieving closure of the apex and thickening of the dentinal walls ${ }^{3-7)}$. A potential disadvantage when using TAP is the possibility of tooth discoloration $^{4,12,13)}$ due to minocycline ${ }^{4,13)}$. The double antibiotic paste (DAP), that excludes minocycline, has also been successfully used for $\mathrm{RET}^{14,15)}$. Other concerns associated with intracanal use of antibiotics are: fear of promoting antibiotic resistance, risk of allergic reaction $^{12)}$ and biocompatibility of the medicament ${ }^{16)}$. An excessive concentration of TAP might affect the host tissue, limiting tissue regeneration ${ }^{17}$. Therefore, the possibility of using chlorhexidine (CHX) or cetrimide (CTR) as intracanal medication in these regenerative procedures could be a safe alternative ${ }^{18}$. In fact, it has recently been reported, that a combination of $2 \%$ CHX gel with $\mathrm{Ca}(\mathrm{OH})_{2}$ as intracanal medicament is as effective as $\mathrm{TAP}^{19)}$.

$E$. faecalis is an opportunistic pathogen associated with different forms of periradicular diseases, including primary $^{20,21)}$ and persistent endodontic infections ${ }^{22)}$. This is due to its ability to adhere to dentin and penetrate along dentinal tubules ${ }^{23)}$ and to colonize the dentin in the form of biofilm ${ }^{24)}$. Its ecologic advantage could allow it to resist the bactericidal effect of $\mathrm{Ca}(\mathrm{OH})_{2}{ }^{23,24)}$, and of a wide range of antibiotics ${ }^{25)}$. In contrast, TAP has shown to be effective against this bacteria ${ }^{26-28)}$. However, there is a lack of consensus, not only referring to the medication used, but also to the length of the treatment, which ranges in literature from 7 days to several weeks ${ }^{3-8,11-14)}$.

To our knowledge, there are no microbiological studies comparing in situ the efficacy of TAP, DAP and $\mathrm{Ca}(\mathrm{OH})_{2}$ paste alone or in combination with $\mathrm{CHX}$ and/ or CTR at different periods of time. Therefore, the aim of this study was to compare the antimicrobial activity of different intracanal medications for 2 and 7 days, in simulated open apex root canals contaminated with $E$. faecalis biofilms.

\section{MATERIALS AND METHODS}

The Ethics Committee of the institution where the experiment was performed previously approved the protocol (UGR-438). The experimental method used in this study was a modification of the model used by Haapasalo and Orstavik ${ }^{29)}$. One hundred and thirty- 
eight single-rooted mature human teeth were stored in $0.1 \%$ thymol solution at $4^{\circ} \mathrm{C}$. After removing $3-4 \mathrm{~mm}$ of the apical third, teeth were decoronated to obtain roots of $8 \mathrm{~mm}$ in length. To standardize the root canal diameter all the canals were enlarged with Peeso drills, sizes 1 up to 4 (Dentsply Maillefer, Ballaigues, Switzerland). To allow handling of the specimens during the experiment, a customized mold was fabricated with polyvinylsiloxane impression material (Zhermack, Rovigo, Italy).

The specimens were placed in an ultrasonic bath with 17\% EDTA ( $\mathrm{pH} 7.2$ ) for 2 min, followed by $5.25 \%$ $\mathrm{NaOCl}$ for $2 \mathrm{~min}$. Each specimen and its corresponding model were autoclaved at $121^{\circ} \mathrm{C}$. As a sterility check, each specimen was placed in a 1.5-mL Eppendorf tube, immersed in sterile brain-heart infusion (BHI) (Scharlau Chemie, Barcelona, Spain), and incubated for 1 week at $37^{\circ} \mathrm{C}$ (inspected daily) to ensure that the BHI broth showed no signs of turbidity. From this stage forward, all specimens were processed using strictly aseptic protocols. From a subculture of $E$. faecalis (ATCC 29212), a 1 McFarland standard suspension was prepared in BHI and then diluted 30-fold to obtain an initial bacterial suspension of approximately $1 \times 10^{7}$ colonyforming units per $\mathrm{mL}(\mathrm{CFU} / \mathrm{mL})$. Afterwards, $1.2 \mathrm{~mL}$ of this suspension and the sterilized specimen were added to an Eppendorf tube and were incubated for 3 weeks under aerobic conditions at $37^{\circ} \mathrm{C}$, with reinoculation performed every 7 days. The cultures were checked for purity by gram stain and colony morphology. The absence of smear layer and open infected dentinal tubules was confirmed under scanning electron microscopy (Fig. 1). Then, each specimen was inserted into its customized mold and the interface between the tooth surface and the impression material was sealed with cyanoacrylate. After the incubation period, samples at baseline were collected from the 128 numbered specimens included in the study, and 10 more specimens ( 5 for each of the follow-up period) without contamination were used as sterility control. The procedure consisted in flooding the canal with a sterile saline solution $(0.9 \%)$ and placing a \#50 Hedström file (Dentsply-Maillefer, Konstanz, Germany) $7 \mathrm{~mm}$ into the root canals (1 $\mathrm{mm}$ above the sample size), to scrape circumferentially the dentin for $15 \mathrm{~s}$, as the apical end of the roots was also sealed with cyanoacrylate to prevent bacterial leakage. Then, two consecutive sterile paper points \#80 were introduced into the canal during $30 \mathrm{~s}$ each. The \#50 Hedström file and the paper points were introduced into a $1.5 \mathrm{~mL}$ Eppendorf tube containing $500 \mu \mathrm{L}$ of BHI broth and vortexed for $30 \mathrm{~s}^{30,31)}$. After, a serial of 5 ten-fold dilutions were prepared and plated in BHI medium for viable cell counting as Colony Forming Units (CFUs).

From the 128 specimens, 64 were randomly assigned to 2 or 7 days follow-up periods, and then, subdivided into 8 groups ( $n=8 /$ group) as follows: Group 1: TAP, containing equal amounts of metronidazole, ciprofloxacin, and minocycline $(0.5 \mathrm{mg} / \mathrm{mL})$; Group 2: DAP, containing equal amounts of ciprofloxacin and metronidazole $(0.5 \mathrm{mg} / \mathrm{mL})$; Group 3: Dental base paste (DBP), consisting of $20 \%$ calcium hydroxide, $50 \%$

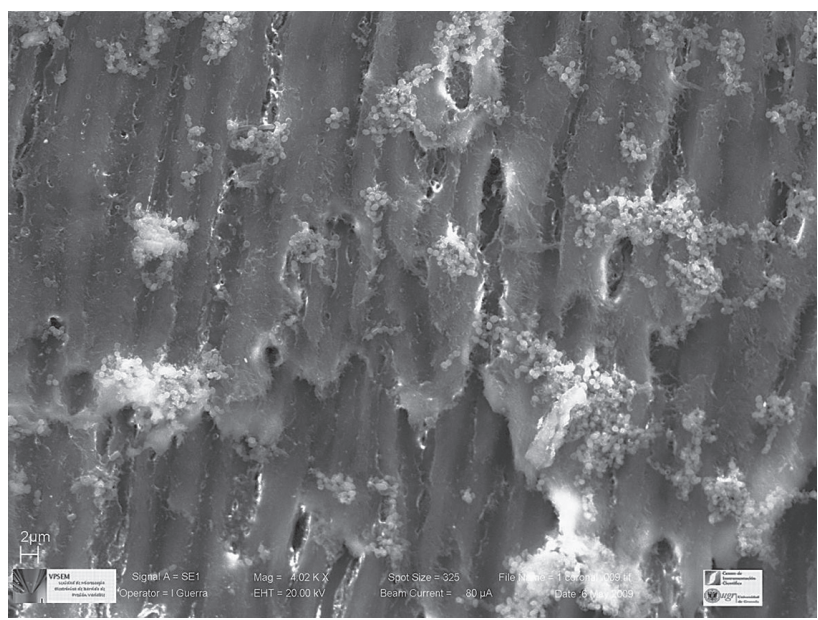

Fig. 1 Scanning electron microscopy micrograph. The absence of smear layer and open infected dentinal tubules can be observed.

propylene glycol and 30\% calcium carbonate; Group 4: $\mathrm{DBP}+0.2 \%$ CHX paste; Group 5: $\mathrm{DBP}+0.2 \%$ Cetrimide (CTR) paste; Group 6: DBP+0.2\% CHX+0.2\% CTR paste; Group 7: irrigation with $20 \mathrm{~mL}$ of $2.5 \% \mathrm{NaOCl}$, and Group 8: irrigation with $20 \mathrm{~mL}$ of distilled water.

Canals were irrigated with $20 \mathrm{~mL}$ of sterile water, dried with paper points and the medicaments were introduced using a syringe and sterile needles in receding from apical to coronal part. The coronal access was sealed with a sterile cotton pellet and the specimens were incubated for 2 and 7 days respectively. Afterwards, the medication was removed with $80 \mathrm{~mL}$ of sterile water and the second microbiological sampling (post-treatment) was performed as previously described.

\section{Statistical analysis}

The results were expressed as $\log _{10}(\mathrm{CFUs}+1)$ reduction, where CFUs stands for "colony forming units" and +1 is the general convention to allow log calculation in the event $\mathrm{CFU}=0$. For each group the differences between the first sampling (at baseline) and the second sampling after medication were calculated. The term 'no growth' (NG) was used to denote that no culturable bacteria were recovered in any specimen/group. A $\log _{10}$ reduction $>3$ can be considered highly effective.

Once the ANOVA had rejected the hypothesis of equality of groups, a Tukey test was applied for multiple comparisons among samplings at baseline and posttreatment. In order to compare the efficacy of the two follow-up periods (2 and 7 days) a Student's $t$-test was performed. The level of statistical significance was set at $p<0.05$. All statistical analysis was performed by means of SPSS 18.0 for Windows software (IBM, Armonk, NY, USA). 
Table $1 \quad \log _{10}$ reduction of colony formed units of Enterococcus faecalis in both follow-up periods: 2 and 7 days

\begin{tabular}{lccc}
\hline \multirow{2}{*}{ Groups } & 2 days post-treatment & 7 days post-treatment & \multirow{2}{*}{$*^{*}$} \\
\cline { 2 - 3 } TAP & $\log _{10}$ reduction & $\log _{10}$ reduction & \\
DAP & $3.72(0.26)^{\mathrm{a}}(\mathrm{NG})$ & $3.67(0.18)^{\mathrm{a}}(\mathrm{NG})$ & 0.715 \\
DBP+0.2\% CHX & $3.71(0.13)^{\mathrm{a}}(\mathrm{NG})$ & $3.66(0.14)^{\mathrm{a}}(\mathrm{NG})$ & 0.491 \\
DBP+0.2\% CTR & $3.51(0.25)^{\mathrm{a}}(\mathrm{NG})$ & $3.59(0.26)^{\mathrm{a}}(\mathrm{NG})$ & 0.549 \\
DBP+0.2\% CHX+0.2\% CTR & $3.46(0.21)^{\mathrm{a}}(\mathrm{NG})$ & $3.60(0.15)^{\mathrm{a}}(\mathrm{NG})$ & 0.146 \\
DBP & $3.44(0.36)^{\mathrm{a}}(\mathrm{NG})$ & $3.40(0.22)^{\mathrm{a}}(\mathrm{NG})$ & 0.775 \\
Irrigation with $2.5 \% \mathrm{NaOCl}$ & $3.05(0.80)^{\mathrm{a}, \mathrm{b}}$ & $3.58(0.21)^{\mathrm{a}}(\mathrm{NG})$ & 0.105 \\
Irrigation with distilled water & $2.20(1.37)^{\mathrm{b}, \mathrm{c}}$ & $0.76(1.11)^{\mathrm{b}}$ & 0.038 \\
\hline
\end{tabular}

Comparison between groups and follow-up periods. Mean (SD)

TAP: triple antibiotic paste, DAP: double antibiotic paste, DBP: dental base paste, CHX: chlorhexidine; CTR: cetrimide; $\mathrm{NaOCl}$ : sodium hypochlorite; NG: No growth.

The same superscript letter shows differences that were not statistically significant determined by the Tukey's test once that ANOVA test for 2 and 7 days showed statistically significant differences $(p<0.001$ in both cases).

* Comparison by Student's $t$-test $(p<0.05)$.

\section{RESULTS}

Mean values obtained at baseline in $\log _{10}$ ranged between 3.72 (TAP) and 3.39 (distilled water) for specimens incubated for 2 days without statistical significant differences among the experimental groups evaluated. In the same way, no significant differences for baseline results were recorded among the specimens incubated for 7 days, regardless the treatment applied. In this case, mean values ranged from 3.67 (TAP) to 3.4 (distilled water and $\mathrm{DBP}+0.2 \% \mathrm{CHX}+0.2 \% \mathrm{CTR}$ ).

The results are shown in Table 1. At 2 days post-treatment, TAP, DAP, $\mathrm{DBP}+0.2 \%$ CHX paste, $\mathrm{DBP}+0.2 \%$ CTR paste and DBP $+0.2 \% \mathrm{CHX}+0.2 \% \mathrm{CTR}$ paste exhibited NG of $E$. faecalis. Without achieving NG, $\mathrm{DBP}$ and $2.5 \% \mathrm{NaOCl}$, obtained statistically the same efficacy. The worst results were achieved with distilled water (1.09 $\log _{10}$ reduction).

At 7 days post-treatment $\mathrm{NaOCl}$ and distilled water achieved similar $\log _{10}$ reduction (0.76 and 0.48 , respectively) that was significantly lower than the obtained with the other 6 medications, which showed NG.

Overall, there were no statistical differences between both follow-up time periods ( 2 and 7 days), except for $2.5 \% \mathrm{NaOCl}$ treatment that showed a higher $\log _{10}$ reduction at 2 days.

\section{DISCUSSION}

Various studies have also used E. faecalis to evaluate the antibacterial effectiveness of different intracanal medications, as this strain is highly resistant against different antibacterial agents ${ }^{26,28,32)}$ and it is recovered from root canals of teeth with persistent periapical lesions. Thus, the NG of Enterococcus during root canal treatment is essential ${ }^{21}$, although it must be considered that endodontic infection is polymicrobial.

In general, for all experimental groups, baseline CFUs values were lower, between $10^{3}$ and $10^{4}$, than those reported previously for other authors ${ }^{28,33}$. This could be due to methodological differences, as a lower concentration of the inoculum and/or a shorter root length ${ }^{33}$. These baseline values should be taken into account, since a low microbial load could explain that no growth of Enterococcus was determined for experimental groups in which antibiotics or antiseptics in paste were applied, either at 2 or 7 days post-treatment. Moreover, although sampling at baseline may have some repercussion on the bacterial reduction, as it recovers a small part although representative of the total load, this procedure was similar for all experimental groups and thereby the produced effect.

In the present study DBP, that contained $\mathrm{Ca}(\mathrm{OH})_{2}$, did not show NG capacity of E. faecalis when compared with the other medicaments at 2 days post-treatment. However, this difference disappeared after 7 days, attaining as the others a $100 \%$ of NG capacity. This is consistent with the study by Madhubala et al. ${ }^{26}$ ) in which $\mathrm{Ca}(\mathrm{OH})_{2}$ also showed a gradual increase in its antibacterial activity, although they reported a maximum of $59.4 \%$ on day 7 . Also, Shokraneh et al. ${ }^{28)}$, did not find significant differences between TAP and $\mathrm{Ca}(\mathrm{OH})_{2}$, alone or in combination with CHX, in the deep dentin; although TAP showed a significantly higher antibacterial activity in surface dentin. The good results of $\mathrm{Ca}(\mathrm{OH})_{2}$ in this study could be due to its combination with propylene glycol which is a biologically well- 
accepted vehicle with significant antibacterial properties that allows a sustained release of hydroxyl ions and enhances the diffusivity of calcium hydroxide into the dentinal tubules ${ }^{34)}$.

No differences between $\mathrm{NaOCl}$ and distilled water experimental groups were detected at 2 and 7 days posttreatment, which may be a surprising result a priori. $\mathrm{NaOCl}$ is a strong antimicrobial but with no residual activity $^{35)}$. It loses its activity just after its application, therefore no interference with bacterial regrowth would be expected. This fact could explain that at 2 days post-treatment the difference with the $\log _{10}$ reduction obtained by distilled water was 1 unit and at 7 days differences were even lower (0.28).

TAP has shown to be very effective in eliminating endodontic pathogens in vitro ${ }^{27,36)}$, in situ ${ }^{26,28)}$ and in $v i v{ }^{37}$. In agreement, the application of TAP produced a $100 \%$ reduction of $E$. faecalis at 2 and 7 days posttreatment. This antibacterial efficacy against $E$. faecalis was also reported by Madhubala et al. ${ }^{26)}$, although in their study, TAP required 7 days to show its higher antibacterial effect (98.46\%).

According to our results, DAP was as effective as TAP against $E$. faecalis in the root canal space, agreeing with Sabrah et al. ${ }^{27)}$, who obtained no significant difference between TAP and DAP antimicrobial activity against this bacterium when compared in vitro. This also corroborates the good clinical outcomes of DAP in the cases reports published by Iwaya et $a .^{14)}$ and by Hargreaves et al. ${ }^{15}$. Therefore, the elimination of minocycline could allow obtaining the same clinical results avoiding the risk of tooth discoloration, even so, it still remains the risk of promoting antibiotic resistance, of allergic reaction or toxicity of the medicament.

Despite the satisfactory results of TAP and DAP for RET, it should be borne in mind that medicaments at concentrations currently used could adversely affect stem cells survival ${ }^{2,38}$. According to this, Ruparel et $a l .{ }^{2)}$ showed that TAP and DAP significantly reduced the survival of stem cells of the apical papilla (SCAPs) in a concentration dependent fashion, since lower concentrations of $0.01-0.10 \mathrm{mg} / \mathrm{mL}$ of TAP and DAP did not have an effect on SCAPs, while Chuensombat et $a l .{ }^{17)}$ determined that $0.39 \mathrm{mg} / \mathrm{mL}$ TAP was a safe dose, although it was unable to eradicate all bacteria. Recent recommendations suggest doses no higher than $1 \mathrm{mg} / \mathrm{mL}$ seeking for a balance between safety and antimicrobial effectivity ${ }^{38,39}$.

On the other hand, this detrimental effect on SCAPs survival has not been evidenced for $\mathrm{Ca}(\mathrm{OH})_{2}$ regardless of the concentration tested ${ }^{2)}$; even promoting SCAP survival and proliferation ${ }^{2,38}$. Therefore, medicaments used in RET should be carefully selected and used at adequate concentrations to have antibacterial efficacy without evoking toxicity to the host stem cells ${ }^{2}$. The current clinical recommendation of the American Association of Endodontists ${ }^{40)}$ suggests the use of $\mathrm{Ca}(\mathrm{OH})_{2}$ or $0.1 \mathrm{mg} / \mathrm{mL}$ of TAP. However, a recent study showed that $0.125 \mathrm{mg} / \mathrm{mL}$ of DAP and TAP did not have cytotoxic effect on dental pulp stem cells, but it was not enough to completely eradicate established biofilm of $E$. faecalis, although it showed a significant antibacterial effect $^{32)}$. Nevertheless, the exact concentration used clinically is not usually precisely reported ${ }^{4,5,12,39)}$.

CHX and CTR have proven to be effective against E. faecalis, alone ${ }^{41}$ or in combination ${ }^{42)}$ when used as irrigating solutions, which is in line with the results of this study, where DBP $+0.2 \%$ CHX paste, $\mathrm{DBP}+0.2 \%$ CTR paste and $\mathrm{DBP}+0.2 \% \mathrm{CHX}+0.2 \%$ CTR paste exhibited NG of $E$. faecalis at both experimental periods. In clinical situations, Nagata et al. ${ }^{19)}$ have reported that a paste composed of $\mathrm{Ca}(\mathrm{OH})_{2}+2 \% \mathrm{CHX}$ gel is as effective as TAP. According to this, Soares et al. ${ }^{18)}$ presented a new proposal for pulp revascularization with mechanical decontamination and intracanal medication of $\mathrm{Ca}(\mathrm{OH})_{2}+2 \%$ CHX gel, obtaining a satisfactory root development. However, Ordinola-Zapata et $a .^{43)}$ reported that TAP was more effective than $2 \%$ CHX gel and $\mathrm{Ca}(\mathrm{OH})_{2}$ at killing bacteria in the biofilms of an intraorally infected dentin model. Another study evaluated the viability of $E$. faecalis in human radicular dentin after a 14-day exposure to $\mathrm{Ca}(\mathrm{OH})_{2}$, TAP, $2 \%$ CHX gel and 1\% CTR solution. Both TAP and 1\% CTR significantly reduced the viability of $E$. faecalis in comparison with $2 \% \mathrm{CHX}$ gel and $\mathrm{Ca}(\mathrm{OH})_{2}{ }^{44}$. This could be due to the presentation in gel of the CHX, as according to the results of a pilot study of our research group, in which $0.2 \% \mathrm{CHX}$ gel and $0.2 \% \mathrm{CTR}$ gel, alone or in combination, were much less effective than the paste presentation (data not shown). Further investigation should be carried out to clarify the influence of the mode of presentation of these medicaments on their effectiveness.

Regarding CHX biocompatibility, 2\% CHX solution showed a good biocompatibility when injected subcutaneously in rats, while $2 \%$ CHX gel presented a moderate inflammatory response at 14 days, which decreased at 30 days ${ }^{45)}$. However, in other studies, CHX showed to be cytotoxic on osteoblastic, endothelial and fibroblastic cell lines ${ }^{46)}$ and particularly on $\operatorname{SCAPs}^{47}$. For this reason, in this study $0.2 \%$ CHX was used instead of $2 \%$. Referring to CTR, its biocompatibility has hardly been investigated. Önçağ et al. ${ }^{48)}$ compared the antibacterial properties and toxicity of various root canal irrigants: $5.25 \%$ sodium hypochlorite $(\mathrm{NaOCl})$, $2 \%$ CHX and $0.2 \% \quad \mathrm{CHX}+0.2 \%$ CTR (Cetrexidin ${ }^{\circledR}$ ). Cetrexidin $^{\circledR}$ and $2 \%$ CHX were more effective and had more residual antibacterial effects and lower toxicity than $5.25 \% \mathrm{NaOCl}$.

\section{CONCLUSIONS}

On the basis of the findings reported in this study, it can be concluded that CHX and/or CTR pastes were as effective as DAP and TAP as short-term intracanal medicaments in RET and CTR could be an alternative once its biocompatibility is proven.

Moreover, long periods of intracanal medication would not be required to achieve an effective disinfection of the root canals. However, research is warranted 
to compare the efficacy and biocompatibility of these medicaments and to test them in a mixed species biofilm as well as in a clinical scenario to obtain predictable outcomes and to establish a standardized treatment protocol for necrotic immature permanent teeth.

\section{ACKNOWLEDGMENTS}

The authors are in debt to Mariano Valderrama from the Department of Statistics and Operations Research of University of Granada for his help with the statistical analysis. The authors would also like to thank Francisca Castillo-Pérez and Gertrudis Gómez-Villaescusa for their technical assistance.

This study was supported by the Research Group CTS-167 of the Junta de Andalucía, Spain.

\section{CONFLICT OF INTEREST}

The authors declare that they have no conflict of interest.

\section{REFERENCES}

1) Tziafas D, Kodonas K. Differentiation potential of dental papilla, dental pulp, and apical papilla progenitor cells. J Endod 2010; 36: 781-789.

2) Ruparel NB, Teixeira FB, Ferraz CCR, Diogenes A. Direct effect of intracanal medicaments on survival of stem cells of the apical papilla. J Endod 2012; 38: 1372-1375.

3) Banchs F, Trope M. Revascularization of immature permanent teeth with apical periodontitis: new treatment protocol? J Endod 2004; 30: 196-200.

4) Kim JH, Kim Y, Shin SJ, Park JW, Jung IY. Tooth discoloration of immature permanent incisor associated with triple antibiotic therapy: a case report. J Endod 2010; 36: 1086-1091.

5) NosratA, Seifi A, Asgary S. Regenerative endodontic treatment (revascularization) for necrotic immature permanent molars: a review and report of two cases with a new biomaterial. J Endod 2011; 37: 562-567.

6) Jeeruphan $T$, Jantarat J, Yanpiset K, Suwannapan L, Khewsawai P, Hargreaves KM. Mahidol study 1: Comparison of radiographic and survival outcomes of immature teeth treated with either regenerative endodontic or apexification methods: a retrospective study. J Endod 2012; 38: 13301336.

7) Saoud TM, Zaazou A, Nabil A, Moussa S, Lin LM, Gibbs JL. Clinical and radiographic outcomes of traumatized immature permanent necrotic teeth after revascularization/ revitalization therapy. J Endod 2014; 40: 1946-1952.

8) Cotti E, Mereu M, Lusso D. Regenerative treatment of an immature, traumatized tooth with apical periodontitis: report of a case. J Endod 2008; 34: 611-616.

9) Chueh LH, Huang GTJ. Immature teeth with periradicular periodontitis or abscess undergoing apexogenesis: a paradigm shift. J Endod 2006; 32: 1205-1213.

10) Chueh LH, Ho YC, Kuo TC, Lai WH, Chiang CP. Regenerative endodontic treatment for necrotic immature permanent teeth. J Endod 2009; 35: 160-164.

11) Cehreli ZC, Isbitiren B, Sara S, Erbas G. Regenerative endodontic treatment (revascularization) of immature necrotic molars medicated with calcium hydroxide: a case series. J Endod 2011; 37: 1327-1330.

12) Reynolds K, Johnson JD, Cohenca N. Pulp revascularization of necrotic bilateral bicuspids using a modified novel technique to eliminate potential coronal discolouration: a case report. Int Endod J 2009; 42: 84-92.

13) Petrino JA, Boda KK, Shambarger S, Bowles WR, McClanahan SB. Challenges in regenerative endodontics: a case series. J Endod 2010; 36: 536-541.

14) Iwaya S, Ikawa M, Kubota M. Revascularization of an immature permanent tooth with apical periodontitis and sinus tract. Dent Traumatol 2001; 17: 185-187.

15) Hargreaves KM, Diogenes A, Teixeira FB. Treatment options: biological basis of regenerative endodontic procedures. $\mathrm{J}$ Endod 2013; 39: S30-43.

16) Wigler R, Kaufman AY, Lin S, Steinbock N, Hazan-Molina H, Torneck CD. Revascularization: a treatment for permanent teeth with necrotic pulp and incomplete root development. J Endod 2013; 39: 319-326.

17) Chuensombat S, Khemaleelakul S, Chattipakorn S, Srisuwan T. Cytotoxic effects and antibacterial efficacy of a 3 -antibiotic combination: An in vitro study. J Endod 2013; 39: 813-319.

18) Soares AJ, Lins FF, Nagata JY, Gomes BP, Zaia AA, Ferraz CC, de Almeida JF, de Souza-Filho FJ. Pulp revascularization after root canal decontamination with calcium hydroxide and 2\% chlorhexidine gel. J Endod 2013; 39: 417-420.

19) Nagata JY, Soares AJ, Souza-Filho FJ, Zaia AA, Ferraz CCR, Almeida JFA, Gomes BPFA. Microbial evaluation of traumatized teeth treated with triple antibiotic paste or calcium hydroxide with $2 \%$ chlorhexidine gel in pulp revascularization. J Endod 2014; 40: 778-783.

20) Sassone LM, Fidel RA, Faveri M, Figueiredo L, Fidel SR, Feres M. A microbiological profile of unexposed and exposed pulp space of primary endodontic infections by checkerboard DNA-DNA hybridization. J Endod 2012; 38: 889-893.

21) Ferreira NS, Martinho FC, Cardoso FG, Nascimento GG, Carvalho CA, Valera MC. Microbiological profile resistant to different intracanal medications in primary endodontic infection. J Endod 2015; 41: 824-830.

22) Ròças IN, Siqueira JF Jr, Santos KRN. Association of Enterococcus faecalis with different forms of periradicular diseases. J Endod 2004; 30: 315-320.

23) Kayaoglu G, Ørstavik D. Virulence factors of Enterococcus faecalis: relationship to endodontic disease. Crit Rev Oral Biol Med 2004; 15: 308-320.

24) Distel JW, Hatton JF, Gillespie MJ. Biofilm formation in medicated root canals. J Endod 2002; 28: 689-693.

25) Leclercq R. Enterococci acquire new kinds of resistance. Clin Infect Dis 1997; 24: S80-84.

26) Madhubala MM, Srinivasan N, Ahamed S. Comparative evaluation of propolis and triantibiotic mixture as an intracanal medicament against Enterococcus faecalis. J Endod 2011; 37: 1287-1289.

27) Sabrah AH, Yassen GH, Gregory RL. Effectiveness of antibiotic medicaments against biofilm formation of Enterococcus faecalis and Porphyromonas gingivalis. J Endod 2013; 39: 1385-1389.

28) Shokraneh A, Farhad AR, Farhadi N, Saatchi M, Hasheminia SM. Antibacterial effect of triantibiotic mixture versus calcium hydroxide in combination with active agents against Enterococcus faecalis biofilm. Dent Mater J 2014; 33: 733738.

29) Haapasalo M, Orstavik D. In vitro infection and disinfection of dentinal tubules. J Dent Res 1987; 66: 1375-1379.

30) Ferrer-Luque CM, Bejarano I, Ruiz-Linares M, Baca P. Reduction in Enteroccocus faecalis counts - a comparison between rotary and reciprocating systems. Int Endod J 2014; 47: 380-386.

31) Ferrer-Luque CM, González-Castillo S, Ruiz-Linares M, Arias-Moliz MT, Rodríguez-Archilla A, Baca P. Antimicrobial residual effects of irrigation regimens with maleic acid in infected root canals. J Biol Res 2015; 22: 1.

32) Sabrah AH, Yassen GH, Liu WC, Goebel WS, Gregory RL, 
Platt JA. The effect of diluted triple and double antibiotic pastes on dental pulp stem cells and established Enterococcus faecalis biofilm. Clin Oral Investig 2015; 19: 2059-2066.

33) Gomes BP, Souza SF, Ferraz CC, Teixeira FB, Zaia AA, Valdrighi L, Souza-Filho FJ. Effectiveness of $2 \%$ chlorhexidine gel and calcium hydroxide against Enterococcus faecalis in bovine root dentine in vitro. Int Endod J 2003; 36: 267-275.

34) Simon ST, Bhat KS, Francis R. Effect of four vehicles on the $\mathrm{pH}$ of calcium hydroxide and the release of calcium ion. Oral Surg Oral Med Oral Pathol Oral Radiol Endod 1995; 80: 459464.

35) Menezes MM, Valera MC, Jorge AO, Koga-Ito CY, Camargo $\mathrm{CH}$, Mancini MN. In vitro evaluation of the effectiveness of irrigants and intracanal medicaments on microorganisms within root canals. Int Endod J 2004; 37: 311-319.

36) Hoshino E, Kurihara-Ando N, Sato I, Uematsu H, Sato M, Kota K, Iwaku M. In-vitro antibacterial susceptibility of bacteria taken from infected root dentine to a mixture of ciprofloxacin, metronidazole and minocycline. Int Endod J 1996; 29: 125-130.

37) Windley W, Teixeira F, Levin L, Sigurdsson A, Trope M. Disinfection of immature teeth with a triple antibiotic paste. J Endod 2005; 31: 439-443.

38) Althumairy RI, Teixeira FB, Diogenes A. Effect of dentin conditioning with intracanal medicaments on survival of stem cells of apical papilla. J Endod 2014; 40: 521-525.

39) Diogenes AR, Ruparel NB, Teixeira FB, Hargreaves KM. Translational science in disinfection for regenerative endodontics. J Endod 2014; 40: S52-S57.

40) American Association of Endodontists. Considerations for regenerative procedures. Available at: http://www.aae.org/ clinical-resources/regenerative-endodontics/considerationsfor-regenerative-procedures.aspx. Accessed March 12, 2016.
41) Baca P, Junco P, Arias-Moliz MT, González-Rodríguez MP, Ferrer-Luque CM. Residual and antimicrobial activity of final irrigation protocols on Enterococcus faecalis biofilm in dentin. J Endod 2011; 37: 363-366.

42) Arias-Moliz MT, Ferrer-Luque CM, González-Rodríguez MP, Valderrama MJ, Baca P. Eradication of Enterococcus faecalis biofilms by cetrimide and chlorhexidine. J Endod 2010; 36: 87-90.

43) Ordinola-Zapata R, Bramante CM, Minotti PG, Cavenago BC, Garcia RB, Bernardineli N, Jaramillo DE, Hungaro Duarte MA. Antimicrobial activity of triantibiotic paste, $2 \%$ chlorhexidine gel, and calcium hydroxide on an intraoralinfected dentin biofilm model. J Endod 2013; 39: 115-118.

44) Carbajal Mejía JB, Aguilar Arrieta A. Reduction of viable Enterococcus faecalis in human radicular dentin treated with $1 \%$ cetrimide and conventional intracanal medicaments. Dent Traumatol 2016; 32: 321-327.

45) Gomes-Filho JE, Aurélio KG, Costa MM, Bernabé PFE. Comparison of the biocompatibility of different root canal irrigants. J Appl Oral Sci 2008; 16: 137-144.

46) Giannelli M, Chellini F, Margheri M, Tonelli P, Tani A. Effect of chlorhexidine digluconate on different cell types: a molecular and ultrastructural investigation. Toxicol In Vitro 2008; 22: 308-317.

47) Trevino EG, Patwardhan AN, Henry MA, Perry G, DybdalHargreaves N, Hargreaves KM, Diogenes A. Effect of irrigants on the survival of human stem cells of the apical papilla in a platelet-rich plasma scaffold in human root tips. J Endod 2011; 37: 1109-1115.

48) Önçağ Ö, Hoşgör M, Hilmioğlu S, Zekioğlu O, Eronat C, Burhanoğlu D. Comparison of antibacterial and toxic effects of various root canal irrigants. Int Endod J 2003; 36: 423432 . 